\title{
Studi Differential Thermal Analysis dari NiCuZn Ferrite Magnet dan Efek Penambahan Mn
}

\author{
Agus Sukarto Wismogroho,* Wahyu Bambang Widayatno, dan Zulham yahya Firdaus \\ Laboratorium Nanoteknologi dan Micro Analysis, Fisika Bahan Baru, Pusat Penelitian Fisika - LIPI \\ Komplek Puspiptek Serpong, Tangerang Selatan 15310 \\ Intisari \\ Telah dilakukan studi simulasi reaksi dan analisis Differensial Thermal Analysis (DTA) untuk pembentukan \\ ferrite dengan imbuhan $\mathrm{NiO}, \mathrm{ZnO}$ dan $\mathrm{CuO}$, serta variasi substitusi $\mathrm{NiO}$ dengan $\mathrm{MnO}$. Material yang digunakan \\ adalah powder teknis dengan komposisi $\mathrm{NiO}_{(2-X)} \mathrm{MnO}_{X} \mathrm{CuO}_{0.2} \mathrm{ZnO}_{0.6} \mathrm{Fe}_{2} \mathrm{O}_{3}$. Analisis dilakukan dengan \\ DTA buatan LIPI dan simulasi dilakukan dengan data base HSC 5.0. Simulasi Gibs Energy menunjukkan \\ bahwa semua reaksi dapat berlangsung sejak suhu kamar. Namun demikian, kalsinasi terjadi pada suhu \\ $200-300^{\circ} \mathrm{C}$, dan berakhir pada suhu dibawah $450^{\circ} \mathrm{C}$. Substitusi $\mathrm{NiO}$ ke $\mathrm{MnO}$ menurunkan kebutuhan energi \\ untuk reaksi. Substitusi $\mathrm{NiO}$ ke $\mathrm{MnO}$ menunjukkan kecenderungan untuk menurunkan suhu kalsinasi.
}

\begin{abstract}
Study on simulation of reaction and Differensial Thermal Analysis (DTA) of ferrite formation with addition of $\mathrm{NiO}, \mathrm{ZnO}$ and $\mathrm{CuO}$, including $\mathrm{NiO}$ substitution variation with $\mathrm{MnO}$ has been done. The materil utilized in this experiment was technical powder material with composition of $\mathrm{NiO}_{(2-X)} \mathrm{MnO}_{X} \mathrm{CuO}_{0.2} \mathrm{ZnO}_{0.6} \mathrm{Fe}_{2} \mathrm{O}_{3}$. Thermal analysis was carried out using DTA apparatus made in LIPI and simulation was conducted using database from HSC Chemistry 5.0 software. Simulation of Free Gibbs Energy showed that all reaction can be undergo at room temperature. However, calcination was happened at temperature of $200-300^{\circ} \mathrm{C}$, and was finalized at temperature just below $450^{\circ} \mathrm{C}$. Substitution of $\mathrm{NiO}$ with $\mathrm{MnO}$ decrease the energy consumption for reaction. Substitution of $\mathrm{NiO}$ with $\mathrm{MnO}$ showed the tendency of calcinations temperature reduction.
\end{abstract}

KATA KUNCI: Differential Thermal Analysis (DTA), ferrite, $\mathrm{NiO}, \mathrm{MnO}, \mathrm{Fe}_{2} \mathrm{O}_{3}$

\section{PENDAHULUAN}

Gelombang elektromagnetik yang muncul karena penggunaan listrik/ sinyal listrik mengakibatkan munculnya gelombang elektromagnetik di sekeliling penghantar yang bersifat mengganggu. Pada alat-alat yang sensitif sangat diperlukan perlindungan terhadap EMI (Electro Magnetic Interference) atau derau listrik seperti pada alat kontrol, sinyal dan data dijital.

Ferrite core merupakan material dengan permeabilitas yang tinggi dan konduktifitas yang rendah, yang dapat menyerap darau listrik. Hal ini memungkinkan untuk bahan mencegah munculnya eddy current.

Ferrite core dibuat dengan bahan dasar $\mathrm{Fe}_{2} \mathrm{O}_{3}$ dengan kombinasi dengan oksida berstruktur kubik seperti $\mathrm{CuO}$, $\mathrm{ZnO}$ dan $\mathrm{MnO}$. Untuk meningkatkan permeabilitas bahan, telah dikembangkan berbagai metoda pendekatan. Salah satu metoda yang dilakukan adalah dengan memberikan unsur penambah atau mengganti jenis media yang digunakan. Dalam beberapa laporan, telah dilakukan penambahan dengan unsur-unsur seperti Nickel [1-4], Barium [5], Cobalt [6-9], Nb/V.Nb/B[10, 11]. Penambahan unsur-unsur

\footnotetext{
*E-MAIL: agussukarto@yahoo.com
}

ini meningkatkan permeabilitasnya.

Peningkatan permeabilitas juga dapat diperoleh dengan mengontrol ukuran partikel bahan baku dan ukuran butir kristal dari bahan yang dihasilkan[1]. Pengecilan partikel dan pengecilan butir kristal bahan baku pembuat ferrite core menunjukkan peningkatan kualitas bahan yang dihasilkan [1]. Oleh karena itu, pengembangan ferrite core banyak mengarahkan pada rekayasa pembuatan bahan baku berstruktur nano dengan berbagai metoda pendekatan, seperti sol gel combustion[15], ball milling [12-14, 16], Chemical [17], micro emulsion [18], refluksion [19] dan co-precipitation [20].

Disamping itu, untuk meningkatkan nilai ekonomi dari pembuatan ferrite core secara industri, bahan baku material perlu disuplai dari bahan teknis yang pada umumnya memiliki pengotor pada kadar tertentu. Belum banyak laporan mengenai pembuatan ferrite core dari bahan baku teknis yang diperoleh di Indonesia. Untuk mempelajari lebih jauh mengenai karakteristik dari proses menggunakan bahan tersebut, pada penelitian ini dilakukan studi mengenai karakteris thermal komposisi NiZnCu ferrite dan efek substitusi Mn terhadap Ni. Untuk memahami mekanisme kalsinasi, simulasi reaksi kimia proses kalsinasi juga dilakukan. 
TABEL I: Komposisi sampel

\begin{tabular}{|c|c|}
\hline No sampel & Komposisi \\
\hline 1 & $\mathrm{Ni}_{0.2} \mathrm{Cu}_{0.2} \mathrm{ZnO}_{0.6} \mathrm{Fe}_{2} \mathrm{O}_{3}$ \\
\hline 2 & $\mathrm{Ni}_{0.18} \mathrm{Mn}_{0.02} \mathrm{Cu}_{0.2} \mathrm{ZnO}_{0.6} \mathrm{Fe}_{2} \mathrm{O}_{3}$ \\
\hline 3 & $\mathrm{Ni}_{0.16} \mathrm{Mn}_{0.04} \mathrm{Cu}_{0.2} \mathrm{ZnO}_{0.6} \mathrm{Fe}_{2} O_{3}$ \\
\hline 4 & $\mathrm{Ni}_{0.12} \mathrm{Mn}_{0.08} \mathrm{Cu}_{0.2} \mathrm{ZnO}_{0.6} \mathrm{Fe}_{2} \mathrm{O}_{3}$ \\
\hline
\end{tabular}

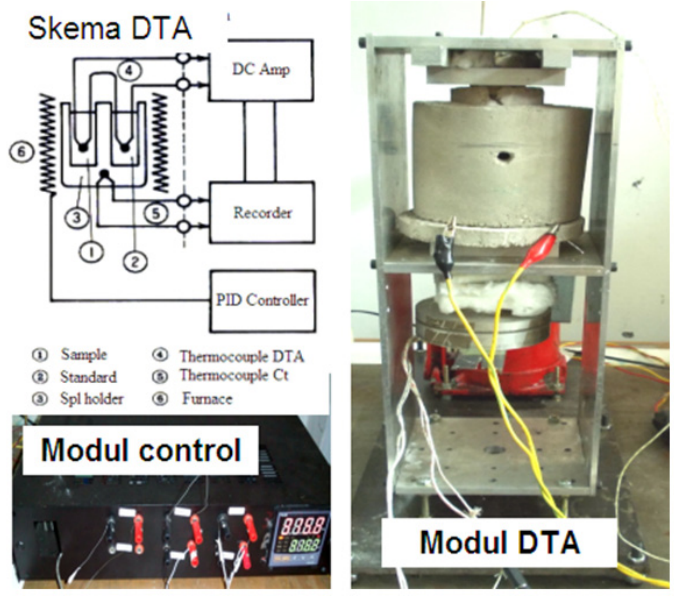

Gambar 1: Skema dan alat DTA yang dikembangkan Pusat Penelitian Fisika - LIPI

\section{METODOLOGI}

Bahan yang digunakan pada penelitian ini adalah $\mathrm{Fe}_{2} \mathrm{O}_{3}$ teknis, $\mathrm{NiO}$ teknis, $\mathrm{MnO}$ teknis dan $\mathrm{ZnO}$ teknis. Masingmasing bahan ditimbang dengan komposisi sesuai dengan komposisi pada Tabel 1.

Bahan dicampur menggunakan High Energy Milling buatan Pusat Penelitian Fisika - LIPI dengan waktu 10 menit untuk mendapatkan campuran yang homoge. Selanjutnya bahan di analisis menggunakan alat DTA buatan Pusat Penelitian Fisika LIPI. Skema dan alat DTA ditunjukan pada Gambar 1.

Untuk mempelajari reaksi kimia antara bahan ferrite dengan material imbuhannya, dilakukan simulasi kimia. Simulasi dilakukan dengan menggunakan software HSC Chemistry 5.0 yang memiliki data base yang mencukupi.

\section{HASIL DAN DIKUSI}

Simulasi kimia dari bahan bahan penyusun ferrite menghitung reaksi kimia antara :

$$
\begin{aligned}
\mathrm{MnO}+\mathrm{Fe}_{2} \mathrm{O}_{3} & \longrightarrow \mathrm{Fe}_{2} \mathrm{MnO}_{4} \\
\mathrm{ZnO}+\mathrm{Fe}_{2} \mathrm{O}_{3} & \longrightarrow \mathrm{Fe}_{2} \mathrm{ZnO}_{4} \\
\mathrm{NiO}+\mathrm{Fe}_{2} \mathrm{O}_{3} & \longrightarrow \mathrm{Fe}_{2} \mathrm{NiO}_{4}
\end{aligned}
$$

Reaksi kimia ferrite ditunjukkan pada rumus kimia (1), (2) dan (3). Delta Gibbs Free Energy dan Delta Enthalpy dihitung menggunakan data base yang ada.

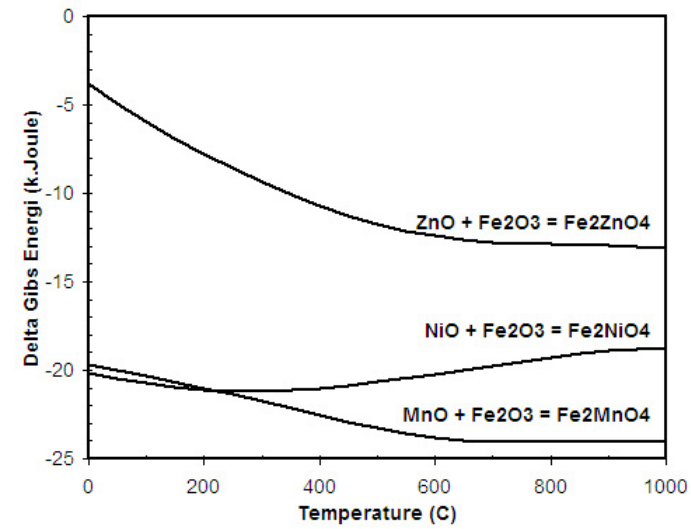

Gambar 2: Simulasi perhitungan Delta Gibbs Energy dari reaksi (1), (2) dan (3).

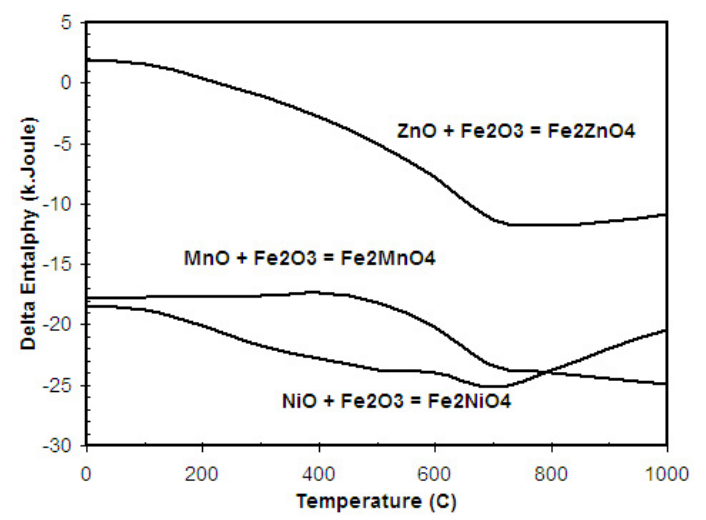

Gambar 3: Simulasi perhitungan Delta Enthalpy dari reaksi (1), (2) dan (3).

Gambar 2 menunjukkan hasil simulasi Delta Gibbs Energy dari reaksi di atas. Dari perhitungan tersebut dapat diketahui bahwa reaksi kimia untuk semua reaksi memiliki posibilitas untuk berjalan secara spontan pada semua suhu reaksi. NiO dan $\mathrm{MnO}$ memiliki nilai yang serupa pada kurun suhu kurang dari $200^{\circ} \mathrm{C}$, dan pada suhu lebih dari itu, $\mathrm{MnO}$ lebih mudah bereaksi disbanding $\mathrm{NiO}$. ZnO memiliki nilai Delta Gibbs energy yang lebih tinggi dibanding yang lain, yang menunjukkan spontanitas reaksi lebih rendah. Namun demikian, secara realita, reaksi tersebut tidak dapat berjalan secara sepontan pada kondisi material yang dicampur di suhu ruang.

Gambar 3 menunjukkan Delta Enthalpy yang menggambarkan reaksi endotermik dan eksotermik dari material. Reaksi NiO memiliki nilai yang paling rendah dibanding ke duanya. $\mathrm{MnO}$ memiliki nilai sedikit lebih tinggi dari $\mathrm{NiO}$, dan $\mathrm{ZnO}$ memiliki nilai yang lebih tinggi.

Gambar 4 menunjukkan hasil analis DTA dari sample yang digunakan. Dari hasil tersebut diketahui bahwa a). kalsinasi/reaksi kimia mulai terjadi bersamaan dengan mulai dinaikkannya suhu proses; b). kalsinasi terjadi pada suhu 200$300^{\circ} \mathrm{C}$, dan berakhir pada suhu dibawah $450^{\circ} \mathrm{C}$; c). substitusi $\mathrm{NiO}$ ke $\mathrm{MnO}$ menurunkan kebutuhan energi untuk reaksi dan cenderung untuk sedikit menurunkan suhu kalsinasi. 


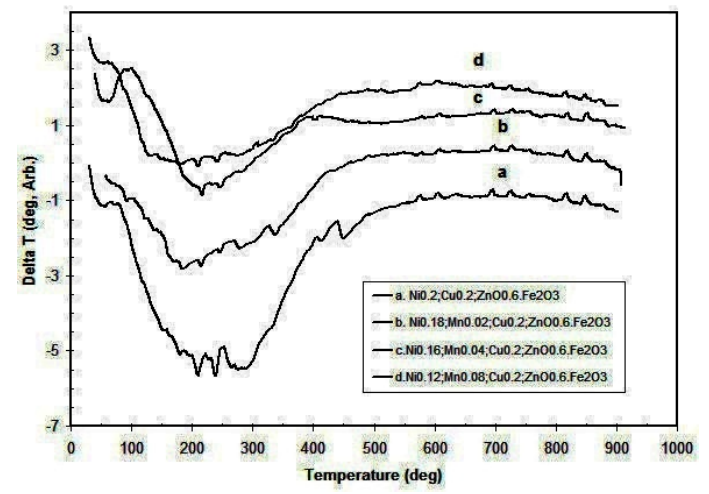

Gambar 4: Hasil analisis DTA untuk sample $\mathrm{a}=1, \mathrm{~b}=2, \mathrm{c}=3, \mathrm{~d}=4$

\section{SIMPULAN}

Telah dilakukan studi simulasi reaksi dan analisis DTA untuk pembentukan ferrite dengan imbuhan $\mathrm{NiO}, \mathrm{MnO}, \mathrm{ZnO}$ dan $\mathrm{CuO}$. Diagram delta Gibs Energy menunjukkan bahwa semua reaksi dapat berlangsung sejak suhu kamar. Namun demikian, kalsinasi terjadi pada suhu $200-300^{\circ} \mathrm{C}$, dan berakhir pada suhu dibawah $450^{\circ} \mathrm{C}$. Substitusi $\mathrm{NiO}$ ke $\mathrm{MnO}$ menurunkan kebutuhan energi untuk reaksi. Substitusi NiO ke $\mathrm{MnO}$ menunjukkan kecenderungan untuk menurunkan suhu kalsinasi.
[1] T. Nakamura, Journal of Magnetism and Magnetic Materials, 168, 285-291 (1997).

[2] P. Priyadharsinia, et al., Materials Chemistry and Physics, 116, 207-213 (2009).

[3] A.C.F.M. Costa, et al., Journal of Alloys and Compounds, 483, 563-565 (2009).

[4] G.S. Shahane, et al., Journal of Magnetism and Magnetic Materials, 322, 1015-1019 (2010)

[5] P. Priyadharsinia, et al., Physica B 404, 689-691 (2009).

[6] N. Petchsang, et al., Journal of Magnetism and Magnetic Materials, 32(13), 1990-1995 (2009).

[7] L. Li, et al., Journal of Alloys and Compounds, 476,(1-2), 755759 (2009).

[8] H. Su, et al., Physica B: Condensed Matter, In Press, 2010.

[9] S. Peng, J. Xie, S. Sun , Journal of Solid State Chemistry, 181 (7), 1560-1564 (2008).

[10] S. H. Chen, et al., Journal of the European Ceramic Society, 21,(10-11), 1931-1935 (2001).

[11] T. Iwamoto, et al., Journal of Colloid and Interface Science,
345,(2), 143-148 (2010).

[12] S. Bid, S.K. Pradhan, Materials Chemistry and Physics, 84, 291-301 (2004).

[13] S. Bid, S.K. Pradhan, Materials Chemistry and Physics, 82, 2737 (2003).

[14] M. Sinha, H. Dutta, S.K. Pradhan, Physica, E 33 , 367-369 (2006).

[15] J. Azadmanjiri, Materials Chemistry and Physics, 109 ,109-112 (2008).

[16] S. Dasguptaa,b, et al., Journal of Magnetism and Magnetic Materials, 306, 9-15 (2006).

[17] P.P. Sarangi, B. Naik, N.N. Ghosh, Powder Technology, 192, 245-249 (2009).

[18] D.S. Mathew, Ruey-Shin Juang, Chemical Engineering Journal, 129, 51-65 (2007).

[19] Z. Zhong, et al., Powder Technology, 155, 193-195 (2005).

[20] M.U. Islama, et al., Solid State Communications, 130, 353-356 (2004). 